\title{
STRATEGIES APPLIED IN TRANSLATING INFORMATION TECHNOLOGY TERMS IN MANUAL BOOKS: IPHONE 12 PRO AND SAMSUNG S20 FE
}

\author{
Eksanti Dwi Pratiwi ${ }^{1 *}$; Ahmad Juma' Khatib² \\ ${ }^{1,2}$ English Literature Program, Faculty of Letters and Cultures, Universitas Gunadarma \\ Jl. Margonda Raya No.100. Pondok Cina, Depok 16424, Indonesia \\ 'eksantidpratiwi@gmail.com; ${ }^{2}$ aj_khatib@staff.gunadarma.ac.id
}

Received: $17^{\text {th }}$ March 2021/Revised: $12^{\text {th }}$ June 2021/Accepted: $14^{\text {th }}$ June 2021

\begin{abstract}
How to Cite: Pratiwi, E. D. \& Khatib, A. J. (2021). Strategies applied in translating information technology terms in manual books: Iphone 12 Pro and Samsung S20 FE. Lingua Cultura, 15(1), 79-84. https://doi.org/10.21512/lc.v15i1.7167
\end{abstract}

\begin{abstract}
The research focused on the translation of technological terms in iPhone 12 Pro and Samsung S20 FE manual books from English into Indonesian. The research applied a descriptive qualitative approach. The Chesterman's translation strategies were used to find out how Information Technology (IT) terms were translated from English into Indonesian. The research finds that four translation strategies are used to translate the manual book of the iPhone 12 Pro and Samsung S20 FE from English into Indonesian. From the total of 60 data, the four strategies are loan (35 data), calque (11 data), unit shift (13 data), and the least used strategies are information change (1 data). It can be concluded that the most frequently used strategies are loan (35 data), while the least used strategies are information change (1 data).
\end{abstract}

Keywords: translation strategy, IT terminologies, manual books

\section{INTRODUCTION}

Era of the $21^{\text {st }}$ century is often regarded as an era of technology (Raja \& Nagasubramani, 2018). Information Technology (IT) plays a vital role in many aspects of people's life. It changes and eases people's life today and is the thing cannot survive without. The impact of technology can be felt in every possible field, from education, economy, to communication. People use many IT products in doing day-to-day tasks. Technology from its various products changes how people communicate, work, eat, learn, entertain, and many more. Nowadays, someone can text from cell phones, connect on social media, take a picture easily with a digital camera, print a document in just one click, or turn on or turn off our bedroom lamp with a remote. Technology products let people find more efficient, faster, and more convenient ways of doing the same thing. Many technological products are being created day by day.

In order to be able to use the new technological products, people need to read manual books. A manual book is a document which is containing information or instructions about a product. Kustanti and Agoes (2017) have stated that people usually read and try to understand the manual book first before using the new object so that they know the steps for using it correctly. To be concluded, reading a manual book is considered necessary. Additionally, Kustanti and Agoes (2017) have also stated that the manual book is an important part of every product. It provides instructions and safety information about the products for the users' convenience.

However, since technological products come and are produced from other countries, the manual books are not written in Indonesian. It is commonly written in English. The difficulty occurs because IT is a new field that brings its own terminologies. According to Multazim and Nurdin (2019), the emergence of technological innovation influences linguistic occurrence in making new terminologies as needed to form words. It can also be difficult for the translator to find the equivalence word, as Ardhinie (2017) has stated that in translating, the translator will find difficulties in looking for the equivalents in the target language. The problem of developing and 
defining IT terminologies is still an issue yet to be solved. The English origin of the terms effects how Indonesian's IT terms are established. Therefore, the researcher is eager to find out how IT terms are translated from English into Indonesian. Translation strategies coined by Chesterman as cited in Gitawati and Said (2014) are used in the research. He has classified translation strategies into three main groups, namely syntactic strategies, semantic strategies, and pragmatic strategies.

Relevant research has been conducted by Saptaningsih (2018). This research aims to discuss the pattern of technical terms translation, focusing on translation technique and translation quality in Sunda Strait Daily News by Kompas.com. The translation techniques are analyzed based on Molina and Albir's theory, and the translation quality is analyzed by Nababan, Nuraeni, and Sumardiono's theory. The examination reveals three patterns used by eight translators in conveying the meaning of technical terms in disaster management. It also pinpoints the ways technical terms in disaster management translated from Indonesian to English.

The second relevant research is conducted by Kustanti and Agoes (2017). This research aims to find out the translation result of similar words and phrases used in source language among Android, iOS, and Windows mobile phones' manual books, and to find out the translation technique mostly used in translating the similar words and phrases of Android, iOS, and Windows mobile phones' manual books. The methods of this research are, first step, collecting the data. The next step is analyzing those data. The step in analyzing the data as to be seen as electing the data, reading the manual books, identifying the similar words and phrases at each part of the manual book, identifying the translation technique used in translating mobile phones' manual books, recording the similar words and phrases, and translating technique found into table form, and the last is the conclusion. The results show that there are 100 similar words and phrases found, and there are eight translation techniques used. They are adaptation, amplification, borrowing, calque, establish equivalent, discursive creation, generalization, and particularization. Furthermore, the most used is calque with the percentage 35\% in Android, 41\% in $\mathrm{iOS}$, and $39 \%$ in Windows mobile phone's manual books.

The thrid relevant research is conducted by Noftariani (2019). This research aims to identify the cultural categories and the translation techniques in the novel entitled Origin by Dan Brown (Indonesian version). This research uses a descriptive qualitative method. Noftariani (2019) has used some theories by Newmark; Molina and Albir; and Nida and Taber to analyze the data related to cultural terms and translation techniques. The results show that there are five kinds of cultural strategies, namely: (1) ecology, (2) material culture, (3) social culture, (4) organizations, customs, activities, procedures, concepts, and (5) gestures and habits. While there are 16 types of translation techniques, namely: addition, adaptation, amplification, borrowing, compensation, description, deletion, discursive creation, established equivalence, generalization, literal, modulation, particularization, reduction, transposition, and variation.

The similarity from the three of previous research is that all researchers analyze the object, which has special terminology: (1) technical terminologies, (2) information technology (IT) terminologies, and (3) cultural terminologies. Whereas the differences among the three previous research are the research's objects: (1) Saptaningsih (2018) uses daily news as the research object, (2) Kustanti and Agoes (2017) use a manual book in their research, and (3) Noftariani (2019) uses English and its translation novel as the research object. Other differences among the three previous pieces of research are their objective's research: (1) Saptaningsih (2018) aims to discuss the pattern of technical terms translation with the focus on translation technique and translation quality, (2) Kustanti and Agoes (2017)'s aim is to find out the translation result of similar words and phrases used in source language among Android, iOS, and Windows mobile phones' manual books, and to find out the translation technique mostly used in translating the similar words and phrases of Android, iOS, and Windows mobile phones' manual books, and (3) Noftariani (2019) in her research aims to identify the cultural categories and the translation techniques.

Related to the theory of translation strategies, Chesterman has classified translation strategies into three main groups, namely syntactic strategies, semantic strategies, and pragmatic strategies (Gitawati $\&$ Said, 2014). Syntactic strategies are primarily the manipulate form. Syntactic strategies are (1) literal translation, which is a translation strategy that is maximally close to the SL form, but grammatical, (2) loan or calque, is the borrowing of individual items and the borrowing of syntagma in the TL translation, (3) transposition is a translation strategy which includes a change of word-class, e.g., from noun to verb, adjective to an adverb, (4) unit shift, is a shift that occurs when a source language unit is translated as a different unit in the target language, (5) phrase structure change which occurs when a source language (SL) phrase structure is translated as a different phrase structure in the target language (TL) without altering the meaning of the source text, (6) clause structure change is a change of clause into another form in the target text translation, (7) sentence structure change's definition is a change of sentence structure in the source text to target text translation. The included changes are changes of main-clause and sub-clause status, changes of sub-clause types, etc., (8) cohesion change is something that affects intra-textual reference, ellipsis, substitution, pronominalization, and repetition, or the use of connectors of various kinds, (9) level shift is a shifted from one level to another, and (10) scheme change which the kinds of changes that translators incorporate in the translation of rhetorical schemes, such as parallelism, repetition, alliteration, metrical rhythm, etc. There are four types of scheme changes that the translator can use: (1) ST scheme $\mathrm{X} \rightarrow \mathrm{TT}$ 
scheme X, (2) ST scheme X $\rightarrow$ TT scheme Y, (3) ST scheme $X \rightarrow$ TT scheme $\varnothing$, and (4) ST scheme $\varnothing \rightarrow$ TT scheme X.

Semantic strategies manipulate nuances of meaning, including synonymy, antonymy, hyponymy, converse, abstraction change, distribution change, emphasis change, paraphrase, and trope change. Here are the description of semantic strategies: (1) synonymy, which selects not the 'obvious' equivalent but a synonym or near-synonym for it, e.g., to avoid repetition, (2) antonymy, in this strategy, the translator selects an antonym of the equivalent and combines it with a negation element, (3) hyponymy, which refers to the generalization using subordinators or the specification using hyponyms of the SL text in TT, (4) converses is defines as pairs of (usually) verbal structures, which express the same state of affairs from opposing viewpoints, (5) abstraction change which refers to abstraction change as a different selection of abstraction level may either move from abstract to more concrete or from concrete to more abstract, (6) distribution change means the distribution of the 'same' semantic components over more items (expansion) or fewer items (compression), (7) emphasis change, which refers to the strategy which adds to, reduces, or alters the emphasis or thematic focus, for one reason or another, (8) paraphrase, which described as loose, free, in some contexts even under-translated, (9) trope change which refers as a set of strategies that apply to the translation of rhetorical tropes such as figurative expressions.

Pragmatic strategies are the last translation strategies. It manipulates the message of the text. This group includes cultural filtering, explicitness change, information change, interpersonal change, illocutionary change, coherence change, partial translation, visibility change, trans-editing, and other pragmatic changes. (1) Cultural filtering, the translation of culturally specific terms into another cultural and or functional equivalents in the target text, (2) explicitness change, (3) information change means either the addition or omission of information that is regarded to be irrelevant, (4) interpersonal change strategy is a strategy which changes the level of the whole style of the text, for example, the formality level, (5) illocutionary change is the changes in the speech act, for example when the translator changes the mood of the verb from indicative to imperative, (6) partial translation, is the translation which covers any partial translation such as summary translation and transcription, (7) visibility change, is the translation strategy which is including the presence of the translator for example by adding footnotes or bracketed comments (to explain puns, for example), and (9) trans-editing is a strategy which is applied when the translator has to deal with poorly written original texts.

The researchers expect the research would give some benefits for the readers. It is expected that this research could give the knowledge how IT terms are translated from English into Indonesian. Furthermore, the other benefits, the researcher also hopes it can be used as a reference for other researchers in conducting research relating to the translation of IT terms.

\section{METHODS}

The research is conducted in a descriptive qualitative approach. It is used because the research does not include any calculation or numeration. The data are produced in the form of words. Further, according to Semiawan, as cited in Alyfia and Setiarini (2020), qualitative is usually in the form of words or text. The research is intended to find out the translation strategies of IT terms in the manual book. The data sources that have been chosen by the researcher are (1) manual books of iPhone 12 Pro (Apple Inc., 2020) and (2) manual books of Samsung S20FE (Samsung Electronics Co. Ltd., 2020). Those objects are chosen because Samsung and Apple are the top two mobile phone manufacturers in the world. Additionally, iPhone 12 pro and Samsung S20 FE are chosen because it is the lastest product of the phone cells of Apple and Samsung in 2020.

In selecting the data to be analyzed, the researchers use the purposive sampling technique. This technique is used to select which data are in accordance with the research objectives so that it can be selected and sampled. The researchers are leaving the data that are not in accordance with the purpose of the research. In analyzing the data, it is chosen randomly as each of them has an equal chance to be analyzed. The data are collected from the text in the user manual book of iPhone 12 Pro (Apple Inc., 2020) and Samsung S20 FE (Samsung Electronics Co. Ltd., 2020). The researchers read all the manual books and their translations thoroughly, then collect words, phrases, and clauses related to IT terms. In the next step, the researchers classify and identify the data referring to Chesterman's translation strategy cited in Gitawati and Said (2014). It classifies translation strategy into three main groups: syntactic strategies, semantic strategies, and pragmatic strategies (Gitawati \& Said, 2014).

\section{RESULTS AND DISCUSSIONS}

Chesterman has classified translation strategies into three main groups, namely syntactic strategies (literal, loan, calque, transposition, unit shift, phrase structure change, clause structure change, sentence structure change, cohesion change, level shift, scheme change), semantic strategies (synonymy, antonymy, hyponymy, converses, abstraction change, emphasis change, paraphrase, trope change), and pragmatic strategies (cultural filtering, explicitness change, information change, interpersonal change, illocutionary change). The research findings from the total 60 data show only four translation strategies in the manual book of iPhone 12 Pro (Apple Inc., 2020) 
and Samsung S20 FE (Samsung Electronics Co. Ltd., 2020); they are loan, calque, unit shift, and information change. The frequencies of the translation strategies are shown in Table 1.

Table 1 Translation Strategies Frequency

\begin{tabular}{ccc}
\hline No. & Translation Strategies & Amount \\
\hline 1. & Loan & 35 \\
2. & Calque & 11 \\
3. & Unit shift & 13 \\
4. & Information change & 1 \\
\hline Total & & 60 \\
\hline
\end{tabular}

There are 60 total data found in the manual book of iPhone 12 Pro and Samsung S20 FE. The manual book of the iPhone 12 Pro contains 10 data, and the manual book of Samsung S20 FE contains 50 data. From Table 1, it can be seen that from 60 data found, there are 35 occurrences of translation strategy loan, 11 data for strategy calque, 13 data for strategy unit shift, and one data belongs to information change. Some of the discussion analysis are shown in Table 2.

Table 2 Datum 1

\begin{tabular}{ll}
\hline \multicolumn{1}{c}{ Source Text } & \multicolumn{1}{c}{ Target Text: Loan } \\
\hline Selfie colour tone: Set a & Rona warna selfie: \\
tone to apply when you take & $\begin{array}{l}\text { Mengatur gaya yang akan } \\
\text { digunakan saat mengambil }\end{array}$ \\
selfies. & foto selfie. \\
\hline
\end{tabular}

In Table 2, the word 'selfie' in English is translated into 'selfie' in Indonesia. According to the Oxford Learner's Dictionaries Online, 'selfie' means a photo of yourself that you take, typically with a smartphone or webcam, and usually put in your social media. The word 'selfie' is a loan word in the Indonesian target text. The equivalent word of 'selfie' in Indonesian is 'swafoto'. According to Kamus Besar Bahasa Indonesia Online, 'swafoto' is potret diri yang diambil sendiri dengan menggunakan kamera ponsel atau kamera digital, biasanya untuk diunggah ke media sosial. The definition of 'selfie' in Oxford Learner's Dictionaries Online and in Kamus Besar Bahasa Indonesia Online is similar.

Table 3 Datum 2

\begin{tabular}{ll}
\hline \multicolumn{1}{c}{ Source Text } & Target Text: Loan \\
\hline The device contains a built-in & $\begin{array}{l}\text { Perangkat mengandung } \\
\text { antenna NFC internal }\end{array}$ \\
NFC antenna. & P
\end{tabular}

In Table 3, the English source text 'NFC', according to the Oxford Learner's Dictionaries Online, is an abbreviation that stands for Near Field Communication (NFC). It is a type of technology that allows communication over short distances between mobile phones and other electronic devices in order to make payments. In Table 3, the word 'NFC' in the Indonesian target text is a loan words, which delivers from English 'NFC'.

Table 4 Datum 3

\begin{tabular}{ll}
\hline \multicolumn{1}{c}{ Source Text } & \multicolumn{1}{c}{ Target Text: Loan } \\
\hline If the lower part of the device & Jika bagian bawah \\
overheats, it could be because & perangkat terlalu panas, \\
the connected USB cable is & hal ini dapat terjadi \\
damaged. & $\begin{array}{l}\text { karena kabel USB yang } \\
\text { terhubung rusak. }\end{array}$ \\
\hline
\end{tabular}

In Table 4, The Oxford Learner's Dictionaries Online defines USB as an abbreviation for Universal Serial Bus. It is the system for connecting other pieces of equipment to a computer. It is translated into 'USB' in Indonesian target text and kind of loan words derived from English 'USB'.

Table 5 Datum 4

\begin{tabular}{l} 
Source Text \\
Target Text: Calque \\
\hline Don't attempt to Jangan mencoba mengganti \\
replace the iPhone baterai iPhone sendiri-Anda \\
battery yourself- dapat merusak baterai, yang \\
you may damage the dapat menyebabkan baterai \\
battery, which could menjadi terlalu panas, terbakar \\
cause overheating, dan mencederai Anda. \\
fire and injury.
\end{tabular}

In Table 5, the English word 'battery' is translated into 'baterai' in the Indonesian target text. According to the Oxford Learner's Dictionaries Online, 'battery' is a device that is placed inside of electrical things that produce electricity, which makes the things work. While Kamus Besar Bahasa Indonesia Online defines baterai as alat untuk menghitung dan membangkitkan aliran listrik. Baterai is an Indonesian calque word since its part of the word is from another language (English).

Table 6 Datum 5

\begin{tabular}{ll}
\hline \multicolumn{1}{c}{ Source Text } & \multicolumn{1}{c}{ Target Text: Calque } \\
\hline The device may require & Perangkat mungkin me- \\
a connection to a Wi-Fi & merlukan koneksi ke Wi-Fi \\
or mobile network when & $\begin{array}{l}\text { atau jaringan seluler saat } \\
\text { menggunakan beberapa } \\
\text { using some application or } \\
\text { features. }\end{array}$ \\
\hline
\end{tabular}

In Table 6, the English word 'application' is translated into Indonesian 'aplikasi'. According to the Oxford Learner's Dictionaries Online, 'application' can be abbreviated as the app designed to do a particular job, a piece of software. It is translated into 'aplikasi' 
in Indonesia by conforming to its pronunciation and grammatical norms.

\section{Table 7 Datum 6}

\begin{tabular}{ll}
\hline \multicolumn{1}{c}{ Source Text } & \multicolumn{1}{c}{ Target Text: Unit Shift } \\
\hline $\begin{array}{l}\text { During wireless charging } \\
\text { or fast charging, the device } \\
\text { may feel hotter to the touch. }\end{array}$ & $\begin{array}{l}\text { tanpa } \text { cepabel atau pengisian daya } \\
\text { terasa panas saat disentuh. }\end{array}$ \\
\hline
\end{tabular}

In Table 7, the English source text 'wireless' is translated into 'tanpa kabel' in the Indonesian target text. According to the Oxford Learner's Dictionaries Online, wireless is any system of sending electronic information, such as internet, phone, signals without using wires for the receiving equipment. It is translated correctly into 'tanpa kabel' in Indonesian. Hence, there is a change of unit form of word 'wireless' into the phrase 'tanpa kabel'. This translation is called unit shift.

Table 8 Datum 7

\begin{tabular}{|c|c|}
\hline Source Text & $\begin{array}{l}\text { Target Text: Information } \\
\text { Change }\end{array}$ \\
\hline When you are roaming & $\begin{array}{l}\text { Ketika anda dalam mode } \\
\text { jelajah (roaming) }\end{array}$ \\
\hline
\end{tabular}

In Table 8, according to the Oxford Learner's Dictionaries Online, 'roaming' uses a mobile phone by connecting to a different company's network, for example, when you are in a different country. The word 'roaming' is translated into 'mode jelajah (roaming)' in the Indonesian target text. There is additional information in the Indonesian target text 'mode jelajah'; thus, this translation is called information change.

Hence, based on the previous researches, it is proved that borrowing (loan and calque) is mainly used in translating particular terminologies. It occurs because terminologies have their own vocabulary. Furthermore, Noftariani (2019) has also stated that the translator often borrows the words from the source text to the target text to make the translation more acceptable and easy to understand. In her research, she also states that borrowing (loan and calque) is the easiest translation technique. The translator does not need to find deep equivalence meaning using other words in the target text.

\section{CONCLUSIONS}

Based on the data analysis, the research shows that from 30, all strategies proposed by Chesterman cited in Gitawati and Said (2014). From the loan as syntactic strategies to other pragmatic strategies, four strategies are used in the translation of IT terms on iPhone 12 Pro's manual book and Samsung S20 FE's manual book. The four strategies are 35 data of loan, 11 data of calque, 13 data of unit shift, and 1 data belongs to information change. The most frequently used strategy is a loan, and the least used strategy is information change. IT terms found in the iPhone 12 Pro's manual book and Samsung S20 FE's manual book are translated by manipulating the form with syntactic strategies. Syntactic strategies are functional in bringing changes in the target language structure of the target language.

Based on the current result, the research gives contribution and implications to the existing translation field. It gives the understanding of how to translate particular terminologies, especially IT terms. Although, there still is a need for a more comprehensive study about this topic. The research is relatively small and limited to the translation of IT terms in the phone's manual book. It would be desirable to conduct further research on translation of IT terms in different literary works, fiction novels, or IT textbooks.

\section{REFERENCES}

Alyfia, H., \& Setiarini, N. L. P. (2020). The interpersonal meaning analysis of Michelle Obama's speech. Jurnal KATA, 5(1), 21-26. https://doi.org/10.22216/ kata.v4i2.4504.

Apple Inc. (2020). iPhone user guide. Retrieved from https://manuals.info.apple.com/MANUALS/1000/ MA1958/en_US/iphone-12-pro-ios14-info.pdf.

Ardhinie, E. (2017). An annotated translation of daughter. Journal of Language and Literature, 3(2), 102-108.

Gitawati, N. D., \& Said, M. (2014). Strategies in translating metonymy: A case study in the translations of the novels exclusive by Sandra Brown and A Pocket Full of Rye by Agatha Christie into Indonesian. Journal of Language and Literature, 1(1), 39-53.

Kustanti, W. T., \& Agoes, F. (2017). An analysis of the translation of procedure text in Android, IOS, Windows operating systems mobile phones manual books. Journal on Aplied English Language, 3(1), 60-69. https://doi.org/10.35313/inggris.v3i1.1279.

Multazim, A., \& Nurdin, E. S. (2019). Word formation of photography terminologies. Journal of Language and Literature, 19(1), 43-54. https://doi.org/10.24071/ joll.2019.1901004.

Noftariani, S. (2019). An analysis of translation techniques used in translating cultural categories in Brown's Origin into Indonesian. JELLT (Journal of English Language and Language Teaching), 3(2), 95-113. https://doi.org/10.36597/jellt.v3i2.5998.

Oxford Learner's Dictionaries. (2021). Oxford Learner's Dictionaries Online. Retrieved from https://www. oxfordlearnersdictionaries.com/

Raja, R., \& Nagasubramani, P. C. (2018). Impact of modern technology in education. Journal of Applied and Advanced Research, 3(1), 33-35. https://doi. 
org/10.21839/jaar.2018.v3is1.165.

Samsung Electronics Co. Ltd. (2020). Samsung user guide. Retrieved from https://www.samsung.com/us/ support/downloads/.

Saptaningsih, N. (2018). Analysis on the translation of technical terms in disaster management: A case study in news translation by novice translators. Surakarta English and Literature Journal, 1(1), 4049. http://ejournal.unsa.ac.id/index.php/selju/editor/ viewMetadata/206. 